Carlos Castello Branco, jornalista, é o autor da Coluna do Castello no Jornal do Brasil.

\title{
A Reforma eleitoral
}

Estabelecida por emenda constitucional, da qual teve a iniciativa o presidente da república, a escolha de governadores por eleição direta, restaurados pela anistia os direitos políticos cassados pelo movimento de 1964, extintos os antigos partidos (Arena e MDB) e alteradas as circunstâncias gerais da política brasileira, impôs-se revisão da legislação eleitoral para criar o processo adequado a viabilizar as inovaçð̋es.

De um lado e outro do sistema político surgiram postulaçðes que tornaram difícil uma negociação direta no âmbito do Congresso em torno da nova legislação. Reivindicaçðes do PDS ou de setores do Executivo empenhados no processo provocaram suspeitas de que, tal como nos períodos anteriores a partir de 1966, seriam impostas regras destinadas a favorecer o Governo e a garantir-lhe a maioria do Congresso e o controle do colégio eleitoral.

Para fixar as linhas do debate o governo solicitou do PDS que, sondadas as bancadas e as lideranças regionais, fixasse suas sugestôes para a reforma. Em contrapartida, os partidos de oposição criaram comissão conjunta para elaborar o seu próprio projeto e ameaçaram fundirem-se numa só agremiação, se necessário, para enfrentar projetos "casuísticos" que acaso fossem propostos pela maioria. Restabelecer-se-ia, se tal acontecesse, o bipartidarismo de fato que imperou de 1966 até o último pleito. Essa hipótese, a que era hostil o PT, tornou-se improvável depois de concedido o registro definitivo do PMDB.

AS SUGESTOEES DO PDS - Depois de cem dias de trabaIho, a comissão especial do PDS entregou relatório com suas conclusర̃es ao presidente do partido e o senador José Sarney levou-o pessoalmente ao presidente da república, a quem entregou também uma carta na qual caracterizava não como um projeto mas como sugestర̋es o relatório do seu partido. Reconhecia o senador que não havia consenso do PDS em torno daquelas sugestð̋es, limitando-se assim o partido a sugerir alguns pontos que lhe pareciam propícios para atender a conjuntura eleitoral sem desfigurar a natureza democrática que deve ter uma legislação eleitoral. Ao lado da 
indicação dos temas e dos pontos que ao partido se afiguravam mais importantes, encaminhou-se um projeto de revisão do Código eleitoral, de quarenta artigos, modificando a operação da justiça eleitoral, a sistemática do alistamento e da tomada de votos, permitindo o uso de máquinas de votar onde a justiça considerasse conveniente e a apuração mediante computação eletrônica. do PDS:

São os seguintes os principais pontos fixados no documento

Sublegenda. Sugere-se que o instituto seja estendido à eleição de governador no pleito de 1982 para permitir que todas as correntes partidárias tenham acesso à disputa. A inovação seria transitória e acentua o senador Sarney que importantes lideranças partidárias com larga influência a ela se opø̃em.

Voto vinculado. O partido dividiu-se em três tendências, a dos que pleiteavam o voto vinculado em todos os níveis, de governador a vereador; a dos que pretendiam a vinculação em dois blocos, um para eleiçøes de deputados federais e estaduais e vereadores e outro para as eleiçðes majoritárias de governador, senador e prefeito; e finalmente um terceiro que optava pela vinculação apenas das eleiçס̃es de deputados e vereadores. O partido considera útil a última dessas propostas. Sabe-se que esse assunto divide o Congresso e o PDS, pois a vinculação total seria um salto no escuro, a de døis blocos geraria outro tipo de dificuldades e a terceira encareceria a eleição de deputados federais, que se veriam constrangidos a financiar direta ou indiretamente as campanhas dos candidatos a vereador.

Proibição de coligações. Também nesse item, o senador Sarney acentua divergências de cúpula no partido, mas a comissão especial opinou em favor da sua adoção.

Voto voluntário. A comissão do PDS declara não ter uma sugestão concreta a dar e espera que o Governo, com seus métodos próprios de avaliação e visão mais ampla do problema político, faça sua op-
ção.

Voto do analfabeto. Envolve riscos sua adoção imediata, sendo conveniente melhor estudo para sua posterior adoção. Em todo o caso, o PDS prefere que o Palácio examine a questão sob os mesmos argumentos usados relativamente ao item anterior.

Propaganda eleitoral. Reintroduzida a propaganda gratuita por rádio e televisão como capítulo do Código eleitoral revisto, o PDS propõe que ela se faça nos quarenta dias anteriores à eleição, em dois turnos diários, sendo o tempo proporcionalmente dividido entre os partidos de acordo com sua representação no Congresso Nacional. Tal dispositivo asseguraria ao PDS mais da metade do tempo de propaganda em todo o território nacional. Prevê-se também que, no âmbito estadual, somente os partidos que apresentem candidato a governador e, no âmbito municipal, os que apresentem candidato a prefeito, tenham direito à propaganda gratuita. Esse dispositivo se prende à proibição de coligações, pois o tempo a que teria direito um partido que não apresente candidato a governador seria redistribuído aos demais, também proporcionalmente. O projeto do PDS propõe expressamente que os candidatos e os dirigen- 
tes de partido, mesmo durante a campanha gratuita, compareçam a programas jornalísticos de rádio e televisão, para entrevistas e debates e possibilita a compra de tempos curtos para difusão de jingles pelo preço corrente das emissoras.

A PROPOSTA DA OPOSIÇÃO - Os partidos da oposição, PMDB, PP, PDT e PT, aprovaram por seus presidentes, sujeita ainda à ratificação pelos respectivos diretórios, sua própria proposta de reforma eleitoral. São os seguintes seus principais itens:

Eleição direta do presidente. O presidente da república deverá ser eleito, a partir de 1984, pelo sufrágio universal direto e secreto e o mandato presidencial voltaria a ser de cinco anos, sem prejuízo do mandato do presidente Figueiredo.

Voto distrital. Para prevenir qualquer tentativa de implantação do voto distrital, a comissão oposicionista propôs emenda constitucional pela qual se declare que a eleição de deputado se fará pelo voto direto, proporcional e secreto. Esse tema do voto distrital, embora seja da simpatia do Governo e de alguns dirigentes do PDS, não consta do elenco de sugestões do PDS.

Sublegenda e voto vinculado. Um projeto de lei proporia a extinção da sublegenda em todos os níveis, inclusive nos pleitos municipais, e proibiria a vinculação de votos, inclusive a que vem sendo adotada de vinculação de votos de deputados federais e estaduais.

Voto do analfabeto. As oposições propõem sem restrições o voto do analfabeto e o uso de símbolos para que o eleitor nessas condições possa fazer suas opções. $\mathrm{O}$ analfabeto não seria contudo elegivel.

Cédulas eleitorais. O projeto das oposições propõe a votação em dois momentos, um para o pleito municipal e outro para os pleitos federal e estaduais. Seriam usadas cédulas coloridas de formato diferente.

Coligações partidárias. Seriam permitidas expressamente as coligações partidárias e protegidas na distribuição dos horários de propaganda gratuita pelo rádio e televisão.

Propaganda eleitoral. Em matéria de propaganda eleitoral, as oposições ampliam o prazo para sessenta dias e estabelecem que será ele distribuído igualmente entre os partidos concorrentes, somando-se, no caso de coligações, os tempos à disposição dos partidos coligados.

Mandatos de partidos derrotados. Propõe-se que sejam validados os mandatos obtidos por candidatos registrados por partidos que não consigam cobrir as exigências constitucionais de obtenção de $5 \%$ da votação nacional e de $3 \%$ da votação em pelo menos nove Estados.

Número de deputados. Contrariando tendência da maioria, não definida na proposta do PDS, a oposição quer estabilizar em 420 o número de deputados.

Representação do Distrito Federal. A oposição pretende que o Distrito Federal volte a ter representação política federal, elegendo três senadores e seis deputados. 
OS PONTOS CRITICOS - Apesar de divergências generalizadas entre os partidos de oposição e o partido do governo, os pontos críticos da reforma eleitoral situam-se na proibição de coligações, na extensão da sublegenda à eleição de governadores, na vinculação de votos e na disciplina da propaganda eleitoral gratuita pelo rádio e a televisão. O PDS não aceita, por sua vez, o princípio da eleição direta do presidente da república, mas também na oposição essa reivindicação não é ponto pacífico. No PP, há divergências a respeito.

Os dois projetos foram formalmente apresentados em agosto. $O$ do governo é fruto da decisão final do presidente e representará o ponto de vista do sistema político no poder. Uma vez formulado, será entregue ao ministro da Justiça para negociação com os demais partidos. A negociação é difícil por não haver compatibilização quanto aos pontos essenciais. Mas o partido do Governo pode transacionar em alguns itens e pode jogar com a exclusão do seu projeto do princípio que anula as restrições da lei complementar $n$. 5, que tornam inelegíveis os punidos pelo movimento militar e os réus de qualquer tipo de processo.

A oposição espera, no entanto, contar com votos do PDS contra a sublegenda, a proibição de coligaçð̃es e a vinculação de votos. A sublegenda, que é reinvidicação de governadores nordestinos, notadamente o sr. Marco Antonio Maciel, de Pernambuco, desatende aos governadores do sul, de Minas Gerais até o Rio Grande e também a um ou outro governador do norte. Na hipótese de não obtenção pelos líderes parlamentares do Governo de garantia para aprovação da sublegenda não é impossível que o Governo autorize negociação em torno do assunto. A vinculação total dificilmente passaria no Congresso, mas a vinculação parcial, de deputados e vereadores parece essencial para o Palácio do Planalto, pois dela poderá depender o controle do colégio eleitoral que, em 1984, mantido o princípio da eleição indireta, escolheria o presidente e o vice-presidente da república. 